\title{
Effect of Natural Cheese Characteristics on Process Cheese Properties
}

\author{
R. Kapoor, ${ }^{*}$ L. E. Metzger, ${ }^{*}$ A. C. Biswas, $†$ and K. Muthukummarappan $\dagger$ \\ ${ }^{*}$ Midwest Dairy Foods Research Center, Department of Food Science and Nutrition, University of Minnesota, St. Paul 55108 \\ †Agricultural and Biosystems Engineering Department, South Dakota State University, Brookings 57007
}

\begin{abstract}
Natural cheese is the major ingredient utilized to manufacture process cheese. The objective of the present study was to evaluate the effect of natural cheese characteristics on the chemical and functional properties of process cheese. Three replicates of 8 natural (Cheddar) cheeses with 2 levels of calcium and phosphorus, residual lactose, and salt-to-moisture ratio (S/ M) were manufactured. After 2 mo of ripening, each of the 8 natural cheeses was converted to 8 process cheese foods that were balanced for their composition, including moisture, fat, salt, and total protein. In addition to the standard compositional analysis (moisture, fat, salt, and total protein), the chemical properties $(\mathrm{pH}$, total $\mathrm{Ca}$, total $\mathrm{P}$, and intact casein) and the functional properties [texture profile analysis (TPA), modified Schreiber melt test, dynamic stress rheometry, and rapid visco analysis] of the process cheese foods were determined. Natural cheese $\mathrm{Ca}$ and $\mathrm{P}$, as well as $\mathrm{S} / \mathrm{M}$, significantly increased total $\mathrm{Ca}$ and $\mathrm{P}, \mathrm{pH}$, and intact casein in the process cheese food. Natural cheese $\mathrm{Ca}$ and $\mathrm{P}$ and $\mathrm{S} / \mathrm{M}$ also significantly affected the final functional properties of the process cheese food. With the increase in natural cheese $\mathrm{Ca}$ and $\mathrm{P}$ and $\mathrm{S} / \mathrm{M}$, there was a significant increase in the TPA-hardness and the viscous properties of process cheese food, whereas the meltability of the process cheese food significantly decreased. Consequently, natural cheese characteristics such as $\mathrm{Ca}$ and $\mathrm{P}$ and $\mathrm{S} / \mathrm{M}$ have a significant influence on the chemical and the final functional properties of process cheese.
\end{abstract}

Key words: natural cheese, calcium, intact casein, process cheese

\section{INTRODUCTION}

Process cheese is obtained by mixing natural cheese and other ingredients, along with emulsifying salts, and using heat and agitation to produce a homoge-

Received November 8, 2006.

Accepted December 12, 2006.

${ }^{1}$ Corresponding author: lmetzger@umn.edu neous product that is used in a variety of forms such as slices, blocks, shreds, and sauces. Natural cheese (mainly Cheddar cheese in the United States) is one of the most important ingredients in process cheese. Depending on the type of process cheese manufactured, the amount of natural cheese in a process cheese formula varies from 51 to $>80 \%$ of the final process cheese (FDA, 2006). Consequently, a substantial portion of Cheddar cheese produced in the United States is used as an ingredient in process cheese manufacture.

The characteristics of natural cheese utilized to manufacture process cheese have a major influence on process cheese characteristics. Numerous researchers have highlighted the importance of natural cheese characteristics on functional properties such as unmelted texture and meltability of process cheese (Barker, 1947; Meyer, 1973; Thomas, 1973; Caric et al., 1985; Shimp, 1985; Zehren and Nusbaum, 2000). Natural cheese made from concentrated milk has also been found to influence the chemical as well as functional properties of process cheese (Acharya and Mistry, 2005). Appropriate selection of natural cheese is important to achieve a process cheese with the desired chemical and functional characteristics. Researchers have highlighted some of the important physicochemical characteristics of a natural cheese that influence the functional properties of process cheese. These include $\mathrm{pH}, \mathrm{Ca}$ content, and age or amount of intact $\mathrm{CN}$ present in the natural cheese (Templeton and Sommer, 1930; Barker, 1947; Olson et al., 1958; Vakaleris et al., 1962; Meyer, 1973; Thomas, 1973; Zehren and Nusbaum, 2000).

The importance of natural cheese $\mathrm{pH}$ on process cheese properties has been highlighted in a study performed by Olson et al. (1958), in which they manufactured Cheddar cheeses with a modified manufacturing protocol so as to produce 2 Cheddar cheese treatments with different final $\mathrm{pH}$ levels. The 2 Cheddar cheeses were then used to manufacture process cheeses (at 10, $30,60,90$, and $150 \mathrm{~d}$ of ripening), which were analyzed for unmelted texture using penetrometry and meltability using the tube melt test. Their results indicated that even after the final $\mathrm{pH}$ of the process cheese was adjusted to 5.4 to 5.5 , the process cheese made using 
Cheddar cheese with the higher $\mathrm{pH}$ was harder and less meltable at all stages of ripening when compared with the process cheese made using Cheddar cheese with the normal $\mathrm{pH}$. There have been no direct studies related to the effect of the level and the state of $\mathrm{Ca}$ of natural cheese on process cheese properties. However, researchers have discussed its importance on process cheese properties (Olson et al., 1958; Zehren and Nusbaum, 2000).

The intact $\mathrm{CN}$ content of natural cheese is inversely related to the age of the natural cheese. As a natural cheese is ripened, its intact $\mathrm{CN}$ content decreases (Garimella Purna et al., 2006). This occurs as the natural cheese ages because the enzymes and residual starter or nonstarter lactic acid bacteria present in the cheese hydrolyze the proteins into peptides, thereby reducing the amount of CN that is still present in an intact (unhydrolyzed) form. Researchers have described the effect of the age of natural cheese on the functional properties of process cheese (Templeton and Sommer, 1930; Arnott et al., 1957; Olson et al., 1958; Vakaleris et al., 1962; Piska and Štětina, 2003; Garimella Purna et al., 2006). All the studies consistently indicate that as the age of natural cheese used in process cheese manufacture increased, the unmelted firmness of the resulting process cheese decreased (Templeton and Sommer, 1930; Olson et al., 1958; Vakaleris et al., 1962; Piska and Štětina, 2003; Garimella Purna et al., 2006), and the meltability of the resulting process cheese increased (Olson et al., 1958; Vakaleris et al., 1962; Garimella Purna et al., 2006).

Previous research has shown that changes in the manufacturing protocols during natural cheese manufacture such as set and drain $\mathrm{pH}$, and level of salting can significantly change the $\mathrm{Ca}$ and $\mathrm{P}$ content, the saltto-moisture ratio percentage $(\mathbf{S} / \mathbf{M})$, and the amount of residual lactose in the natural cheese (Dolby et al., 1937; Czulak et al., 1969; Thomas and Pearce, 1981; Upreti and Metzger, 2006a). Changes in natural cheese $\mathrm{Ca}$ and $\mathrm{P}, \mathrm{S} / \mathrm{M}$, and the amount of residual lactose have been found to affect the physicochemical properties of the natural cheese such as the $\mathrm{pH}$, the state and amount of $\mathrm{Ca}$, as well as the rate and extent of protein hydrolysis (the amount of intact $\mathrm{CN}$ present) in the natural cheese (Czulak et al., 1969; Upreti and Metzger, 2006a).

Czulak et al. (1969) highlighted the effect of drain $\mathrm{pH}$ of Cheddar cheese on the Ca content as well as the final $\mathrm{pH}$ of the cheese. They found that as the $\mathrm{pH}$ of the curd during whey drainage was decreased from 6.14 to 5.75 , there was a $27 \%$ reduction in the total Ca content in the cheese curd at the time of whey separation. They also found that with the decrease in the drain $\mathrm{pH}$ (as indicated above) there was a decrease in the $\mathrm{pH}$ of the cheese from 5.32 to 5.12 at 9 wk of ripening. The level of salting in natural cheese and natural cheese S/M have been found to have an effect on the amount of residual lactose, cheese $\mathrm{pH}$, and rate and extent of protein hydrolysis in cheese. Thomas and Pearce (1981) salted Cheddar cheeses at different rates in ordered to achieve different S/M. They found that, in the cheeses with lower S/M (4\%), lactose was completely utilized in approximately 1 to $2 \mathrm{wk}$ and the $\mathrm{pH}$ of the cheese at $2 \mathrm{wk}$ was 5.08 . In cheeses with $6 \% \mathrm{~S} / \mathrm{M}$, there was $0.31 \%$ residual lactose even after approximately $12 \mathrm{wk}$ of ripening and the $\mathrm{pH}$ of the cheese at $2 \mathrm{wk}$ was 5.31. Moreover, Thomas and Pearce (1981) found that, at $4 \mathrm{wk}$ of ripening, approximately $72.5 \%$ of the major caseins were hydrolyzed in Cheddar cheese with $4 \%$ S/M compared with only approximately $45 \%$ that were hydrolyzed in Cheddar cheese with $6 \%$ $\mathrm{S} / \mathrm{M}$.

Presently, another major thrust in the natural cheese industry is the utilization of concentrated milk to manufacture natural cheeses to increase the throughput of cheese plants. The type of concentration technique and the extent to which milk has been concentrated also influences the $\mathrm{Ca}$ and $\mathrm{P}, \mathrm{S} / \mathrm{M}$, and residual lactose content of the cheese produced (Sutherland and Jameson, 1981; Anderson et al., 1993; Acharya and Mistry, 2004; Nair et al., 2004). Acharya and Mistry (2004) manufactured Cheddar cheeses with milk concentrated using vacuum condensing and ultrafiltration to concentration factors of $1.5 \times$ and $2.0 \times$, respectively. They found that, as the concentration factor of the milk utilized to manufacture Cheddar cheese was increased to 1.5, the Ca content of the Cheddar cheese manufactured increased by $10 \%$ when the milk was ultrafiltered and by $4 \%$ when the milk was vacuum-condensed. Moreover, when the concentration factor of the milk utilized to manufacture Cheddar cheese was increased to 2.0, the calcium content of the Cheddar cheese manufactured increased by $18 \%$ when the milk was ultrafiltered and by $13 \%$ when the milk was vacuum-condensed. Anderson et al. (1993) manufactured reduced-fat Cheddar cheese using condensed milk. They found that as the concentration factor of the milk was increased, the lactose content and S/M of the resulting cheese increased. The lactose content (at $5 \mathrm{~d}$ of ripening) of their cheeses increased from 1.05 to $2.26 \%$, and the S/M increased from 2.88 to $3.74 \%$ in the cheese made using the same cheese milk when concentrated to $2.2 \times$.

The literature cited above indicates that day-to-day variations in natural cheese manufacturing protocols, as well as utilization of concentrated milk to manufacture natural cheese, causes changes in the $\mathrm{Ca}$ and $\mathrm{P}$, residual lactose, and S/M. These changes in natural 
Table 1. Cheese manufacturing protocol used to manufacture the 8 natural cheese treatments

\begin{tabular}{|c|c|c|c|c|}
\hline & $\begin{array}{l}\text { High } \mathrm{Ca} \text { and } \mathrm{P}, \\
\text { High lactose }\end{array}$ & $\begin{array}{l}\text { High } \mathrm{Ca} \text { and } \mathrm{P}, \\
\text { Low lactose }\end{array}$ & $\begin{array}{l}\text { Low } \mathrm{Ca} \text { and } \mathrm{P} \\
\text { High lactose }\end{array}$ & $\begin{array}{l}\text { Low } \mathrm{Ca} \text { and } \mathrm{P}, \\
\text { Low lactose }\end{array}$ \\
\hline Lactose addition & $2.5 \mathrm{~kg} / 100 \mathrm{~kg}$ of milk & - & $2.5 \mathrm{~kg} / 100 \mathrm{~kg}$ of milk & - \\
\hline Starter addition & $54 \mathrm{~mL} / 100 \mathrm{~kg}$ of milk & $54 \mathrm{~mL} / 100 \mathrm{~kg}$ of milk & $27 \mathrm{~mL} / 100 \mathrm{~kg}$ of milk & $27 \mathrm{~mL} / 100 \mathrm{~kg}$ of milk \\
\hline Set $\mathrm{pH}$ & 6.6 & 6.6 & 6.21 & 6.2 \\
\hline Cooking & $\begin{array}{l}37^{\circ} \mathrm{C} \text { in } 30 \text { min and at } \\
37^{\circ} \mathrm{C} \text { for another } 30 \mathrm{~min}\end{array}$ & $\begin{array}{l}37^{\circ} \mathrm{C} \text { in } 30 \text { min } \rightarrow \\
\text { washing } \rightarrow \text { at } 37^{\circ} \mathrm{C} \\
\text { until } 1 \mathrm{~h} \text { of cooking }\end{array}$ & $\begin{array}{l}38^{\circ} \mathrm{C} \text { in } 30 \text { min and } \\
\text { at } 38^{\circ} \mathrm{C} \text { for another } \\
30 \mathrm{~min}\end{array}$ & $\begin{array}{l}38^{\circ} \mathrm{C} \text { in } 30 \mathrm{~min} \rightarrow \text { washing } \\
\rightarrow \text { at } 38^{\circ} \mathrm{C} \text { until } 1 \mathrm{~h} \text { of } \\
\text { cooking }\end{array}$ \\
\hline Drain pH & $6.3-6.4$ & $6.3-6.4$ & 5.7 & 5.7 \\
\hline $\mathrm{pH}$ at salting & 5.4 & 5.4 & 5.4 & 5.4 \\
\hline
\end{tabular}

cheese $\mathrm{Ca}$ and $\mathrm{P}$, residual lactose, and S/M not only influence its chemical properties such as the $\mathrm{pH}$ and intact $\mathrm{CN}$ content, but may also have an effect on the functional properties of the process cheese manufactured from it. Consequently, even if process cheese manufacturers consistently utilize natural cheese from a particular manufacturing facility, they may struggle to produce process cheese with consistent product characteristics. In a previous study performed in our laboratory, we manufactured Cheddar cheese with modified manufacturing protocols to produce Cheddar cheeses with different levels of $\mathrm{Ca}$ and $\mathrm{P}$, residual lactose, and S/M (Upreti and Metzger, 2006a). The compositional differences of the natural cheeses resulted in differences in their physicochemical properties such as total $\mathrm{Ca}$, total $\mathrm{P}, \mathrm{pH}$, and the rate of protein hydrolysis (amount of intact $\mathrm{CN}$ ). The objective of the present study was to utilize the natural cheeses (manufactured in the above indicated study) as an ingredient in process cheese and thereby evaluate the influence of natural cheese $\mathrm{Ca}$ and $\mathrm{P}$, residual lactose, and $\mathrm{S} / \mathrm{M}$ on the chemical as well as the functional properties of process cheese.

\section{MATERIALS AND METHODS}

\section{Experimental Design}

The 3 replicates of 8 different natural (Cheddar) cheeses were manufactured. Each replicate of natural cheese manufacture consisted of 3 factors $(\mathrm{Ca}$ and $\mathrm{P}$, residual lactose, and $\mathrm{S} / \mathrm{M}$ ) at 2 levels for a total of 8 different natural cheese treatments. The 8 treatments were high $\mathrm{Ca}$ and $\mathrm{P}$-high lactose-high S/M (HHH); high $\mathrm{Ca}$ and $\mathrm{P}-$ high lactose-low S/M (HHL); high Ca and P-low lactose-high S/M (HLH); high Ca and Plow lactose-low S/M (HLL); low $\mathrm{Ca}$ and P-high lactose-high S/M (LHH); low Ca and P-high lactose- low S/M (LHL); low $\mathrm{Ca}$ and P-low lactose-high S/M (LLH); and low Ca and P-low lactose-low S/M (LLL).

After manufacture, each of the 8 natural cheeses from all 3 replicates were ripened for 2 mo and subsequently utilized as an ingredient to manufacture 8 different process cheese foods (PC) thereby producing 3 replicates of $8 \mathrm{PC}$ treatments. The $8 \mathrm{PC}$ treatments were process cheese-high $\mathrm{Ca}$ and $\mathrm{P}-$ high lactose-high S/M (PC-HHH); process cheese-high Ca and P-high lactose-low S/M (PC-HHL); process cheese-high Ca and P-low lactose-high S/M (PC-HLH); process cheese-high $\mathrm{Ca}$ and $\mathrm{P}-$ low lactose-low S/M (PCHLL); process cheese-low Ca and P-high lactose-high S/M (PC-LHH); process cheese-low $\mathrm{Ca}$ and P-high lactose-low S/M (PC-LHL); process cheese-low Ca and P-low lactose-high S/M (PC-LLH); and process cheese-low Ca and P-low lactose-low S/M (PC-LLL).

\section{Natural Cheese Manufacture}

Each of the 3 replicates of the 8 natural cheeses was manufactured using a variety of protocols that resulted in a range of $\mathrm{Ca}$ and $\mathrm{P}$, residual lactose, and $\mathrm{S} / \mathrm{M}$ levels. A detailed description of the natural cheese manufacturing protocols followed to produce the above treatments is discussed in a previous paper (Upreti and Metzger, 2006a). Important modifications in the natural cheese manufacture that were utilized to produce the above 8 treatments are summarized in Table 1 (adapted from Upreti and Metzger, 2006a). The compositional differences of the natural cheeses resulted in differences in their physicochemical properties including total $\mathrm{Ca}$, total $\mathrm{P}, \mathrm{pH}$, and rate of protein hydrolysis (amount of intact CN). The mean composition (at 2 mo of ripening) of the 8 natural cheeses manufactured including moisture, fat, protein, salt, S/M, lactose, total $\mathrm{Ca}$, total $\mathrm{P}, \mathrm{pH}$, and intact $\mathrm{CN}$ content is listed in Table 2. 
Table 2. Average chemical composition of the natural cheeses (mean of 3 replicates)

\begin{tabular}{lcccccccc}
\hline & \multicolumn{7}{c}{ Natural cheese treatments $^{1}$} \\
\cline { 2 - 8 } Chemical property & HHH & HHL & HLH & HLL & LHH & LHL & LLH & LLL \\
\hline Moisture, \% & $32.1^{\mathrm{a}}$ & $33.8^{\mathrm{bc}}$ & $33.1^{\mathrm{ab}}$ & $35.2^{\mathrm{de}}$ & $34.1^{\mathrm{bcd}}$ & $35.9^{\mathrm{e}}$ & $34.4^{\text {cd }}$ & $37.6^{\mathrm{f}}$ \\
Fat, \% & $35.9^{\mathrm{a}}$ & $35.0^{\mathrm{ab}}$ & $35.7^{\mathrm{ab}}$ & $34.8^{\mathrm{abc}}$ & $34.5^{\mathrm{bcd}}$ & $33.6^{\mathrm{cd}}$ & $34.7^{\mathrm{abc}}$ & $33.3^{\mathrm{d}}$ \\
Protein, \% & $26.4^{\mathrm{a}}$ & $25.6^{\mathrm{abc}}$ & $26.0^{\mathrm{ab}}$ & $25.3^{\mathrm{bcd}}$ & $25.2^{\mathrm{cd}}$ & $24.8^{\mathrm{cd}}$ & $25.3^{\mathrm{bcd}}$ & $24.5^{\mathrm{d}}$ \\
Salt, \% & $2.0^{\mathrm{bc}}$ & $1.7^{\mathrm{d}}$ & $2.1^{\mathrm{ab}}$ & $1.7^{\mathrm{cd}}$ & $2.3^{\mathrm{ab}}$ & $1.6^{\mathrm{d}}$ & $2.5^{\mathrm{a}}$ & $1.8^{\mathrm{cd}}$ \\
S/M, $\%$ & $6.4^{\mathrm{a}}$ & $5.0^{\mathrm{b}}$ & $6.5^{\mathrm{a}}$ & $4.9^{\mathrm{b}}$ & $6.7^{\mathrm{a}}$ & $4.5^{\mathrm{b}}$ & $7.2^{\mathrm{a}}$ & $4.7^{\mathrm{b}}$ \\
Lactose (d 1), \% & $1.52^{\mathrm{a}}$ & $1.35^{\mathrm{c}}$ & $0.32^{\mathrm{de}}$ & $0.11^{\mathrm{e}}$ & $1.64^{\mathrm{ab}}$ & $1.41^{\mathrm{bc}}$ & $0.49^{\mathrm{d}}$ & $0.27^{\mathrm{e}}$ \\
Total Ca, \% & $0.69^{\mathrm{a}}$ & $0.68^{\mathrm{a}}$ & $0.67^{\mathrm{a}}$ & $0.66^{\mathrm{a}}$ & $0.55^{\mathrm{ab}}$ & $0.54^{\mathrm{b}}$ & $0.55^{\mathrm{b}}$ & $0.51^{\mathrm{b}}$ \\
Total P, \% & $0.48^{\mathrm{a}}$ & $0.48^{\mathrm{a}}$ & $0.48^{\mathrm{a}}$ & $0.47^{\mathrm{a}}$ & $0.42^{\mathrm{a}}$ & $0.42^{\mathrm{b}}$ & $0.41^{\mathrm{b}}$ & $0.40^{\mathrm{b}}$ \\
pH (2 mo) & $5.35^{\mathrm{ab}}$ & $5.16^{\mathrm{bc}}$ & $5.37^{\mathrm{a}}$ & $5.27^{\mathrm{ab}}$ & $5.28^{\mathrm{ab}}$ & $5.07^{\mathrm{c}}$ & $5.27^{\mathrm{ab}}$ & $5.05^{\mathrm{c}}$ \\
Intact CN (2 mo), \% & $23.6^{\mathrm{a}}$ & $22.0^{\mathrm{bc}}$ & $23.0^{\mathrm{ab}}$ & $21.31^{\mathrm{cd}}$ & $21.1^{\mathrm{cd}}$ & $20.0^{\mathrm{e}}$ & $20.8^{\text {de }}$ & $19.4^{\mathrm{e}}$ \\
\hline
\end{tabular}

\footnotetext{
${ }^{\mathrm{a}-\mathrm{e}}$ Means within same row not sharing common superscript are significantly different $(P<0.05)$.

${ }^{1}$ Natural cheese treatments: $\mathrm{HHH}=$ high Ca and $\mathrm{P}$, high lactose, and high salt-to-moisture $(\mathrm{S} / \mathrm{M}) ; \mathrm{HHL}=$ high $\mathrm{Ca}$ and $\mathrm{P}$, high lactose, and low $\mathrm{S} / \mathrm{M} ; \mathrm{HLH}=$ high $\mathrm{Ca}$ and $\mathrm{P}$, low lactose, and high $\mathrm{S} / \mathrm{M}$; HLL = high $\mathrm{Ca}$ and $\mathrm{P}$, low lactose, and low $\mathrm{S} / \mathrm{M} ; \mathrm{LHH}=$ low $\mathrm{Ca}$ and $\mathrm{P}$, high lactose, and high $\mathrm{S} / \mathrm{M} ; \mathrm{LHL}=$ low Ca and $\mathrm{P}$, high lactose, and low S/M; LLH = low Ca and P, low lactose, and high S/M; LLL = low Ca and P, low lactose, and low S/M.

${ }^{2} \mathrm{~S} / \mathrm{M}=$ salt-to-moisture ratio.
}

\section{PC Formulation and Manufacture}

Each of the 8 natural cheeses, from each replicate, were ripened for 2 mo and then utilized as an ingredient to manufacture 3 replicates of 8 different PC treatments. The emulsifying salt used was trisodium citrate (duohydrate; Archer Daniels Midland Company, Decatur, IL). Other ingredients were NDM (low heat; Dairy America, Fresno, CA), anhydrous butter oil (MidAmerica Farms, Springfield, MO), salt, and water. The source of emulsifying salt and other ingredients used to manufacture the $8 \mathrm{PC}$ in each of the 3 replicates was the same. All 8 PC formulations for each of the 3 replicates were developed using Techwizard, an Excelbased formulation software program (Metzger, 2003) provided by Owl Software (Columbia, MO). The detailed ingredient blend and formulations (mean values of the 3 replicates) of the 8 process cheese food treatments are shown in Table 3. The formulation software was used to balance the moisture, fat, salt, and total protein of the resulting $8 \mathrm{PC}$ to 43.0, 25.0, 2.0, and $21.0 \%$, respectively.

All of the PC treatments were manufactured in 4.5$\mathrm{kg}$ batches using a Blentech twin-screw pilot-scale cooker blender (Blentech Corporation, Rohnert Park, CA). During PC manufacture, a preblend was prepared by mixing all the ingredients (indicated above) including natural cheese (4.5-kg batch total) in the Blentech twin-screw cooker at $50 \mathrm{rpm}$ for $30 \mathrm{~min}$ at room temperature to achieve a homogeneous paste. This was followed by increasing the temperature of the preblend to $80^{\circ} \mathrm{C}$ in approximately $5 \mathrm{~min}$ and holding for an additional $5 \mathrm{~min}$. The auger speed throughout the heating and holding stages was $140 \mathrm{rpm}$. Three copper cylinders (20 mm diameter and $30 \mathrm{~mm}$ height) were filled with each of the cooked PC treatments for texture profile analysis (TPA). The cylinders were sealed with

Table 3. Ingredient blend and formulations utilized to manufacture the 8 process cheese treatments (mean of 3 replicates)

\begin{tabular}{|c|c|c|c|c|c|c|c|c|}
\hline \multirow[b]{2}{*}{ Ingredients, $\%$} & \multicolumn{8}{|c|}{ Process cheese treatments ${ }^{1}$} \\
\hline & PC-HHH & PC-HHL & PC-HLH & PC-HLL & PC-LHH & PC-LHL & PC-LLH & PC-LLL \\
\hline Natural cheese (2 mo) & 69.3 & 71.6 & 70.2 & 72.3 & 72.1 & 72.6 & 72.3 & 74.9 \\
\hline Butter oil & 0.1 & 0.1 & 0.0 & 0.0 & 0.2 & 0.5 & 0.2 & 0.0 \\
\hline Salt & 0.3 & 0.6 & 0.3 & 0.5 & 0.1 & 0.6 & 0.2 & 0.5 \\
\hline Trisodium citrate (duohydrate) & 2.5 & 2.5 & 2.5 & 2.5 & 2.5 & 2.5 & 2.5 & 2.5 \\
\hline Water & 21.0 & 18.6 & 19.8 & 17.5 & 18.4 & 17.0 & 17.5 & 14.8 \\
\hline
\end{tabular}

${ }^{1}$ Process cheese treatments: $\mathrm{PC}-\mathrm{HHH}=$ process cheese, high $\mathrm{Ca}$ and $\mathrm{P}$, high lactose, and high salt-to-moisture $(\mathrm{S} / \mathrm{M})$; $\mathrm{PC}-\mathrm{HHL}=$ process cheese, high $\mathrm{Ca}$ and $\mathrm{P}$, high lactose, and low S/M; PC-HLH = process cheese, high Ca and P, low lactose, and high S/M; PC-HLL = process cheese, high $\mathrm{Ca}$ and $\mathrm{P}$, low lactose, and low S/M; PC-LHH = process cheese, low Ca and P, high lactose, and high S/M; PC-LHL = process cheese, low $\mathrm{Ca}$ and $\mathrm{P}$, high lactose, and low $\mathrm{S} / \mathrm{M}$; PC-LLH = process cheese, low Ca and P, low lactose, and high S/M; PC-LLL = process cheese, low $\mathrm{Ca}$ and $\mathrm{P}$, low lactose, and low $\mathrm{S} / \mathrm{M}$. 
Saran wrap and transferred to the cold room $\left(4^{\circ} \mathrm{C}\right)$ after $15 \mathrm{~min}$. The remainder of each $\mathrm{PC}$ was placed in $1-\mathrm{kg}$ boxes and transferred to a cold room $\left(4^{\circ} \mathrm{C}\right)$ after 15 min. All the cooked PC treatments were stored at $4^{\circ} \mathrm{C}$ until further analysis was completed.

\section{Compositional and Chemical Analyses}

The moisture content of the PC produced was analyzed using a vacuum oven as described by Bradley and Vanderwarn (2001). Fat content of the PC was determined using the Mojonnier method (Atherton and Newlander, 1977). Salt content was measured using a Corning Chloride Analyzer 926 (Ciba Corning Diagnostics, Medfield, MA), based on the Volhard test (Marshall, 1992), and $\mathrm{pH}$ was measured with a Corning $\mathrm{pH} / \mathrm{ion}$ meter model 450 (Corning Glass Works, Medfield, MA) with a glass electrode. Total protein in the $\mathrm{PC}$ was determined by measuring total $\mathrm{N}$ in the cheeses using the Dumas combustion method (Leco Tru Spec N analyzer, Leco, St. Joseph, MI; Wiles et al., 1998), and converting it to protein using a multiplication factor of 6.38. Total Ca in the PC was measured using an atomic absorption spectroscopy procedure adapted from Brooks et al. (1970). Total P was determined colorimetrically (AOAC, 1995; method number 991.25). The total intact $\mathrm{CN}$ in each of the $8 \mathrm{PC}$ was calculated by taking into account the amount of intact CN provided by each ingredient utilized in that PC formula; that is, intact $\mathrm{CN}$ of the natural cheese used in the formula (Table 2) and the intact CN from the NDM utilized in the formula. For NDM, the value of intact CN $(28.9 \%)$ was calculated from the total protein present in the NDM. The formula utilized to calculate the intact $\mathrm{CN}$ in process cheese is indicated below.

$$
\begin{aligned}
& \text { Percentage calculated intact } \mathrm{CN}=[(\% \text { IC cheese }) \\
& \times(\% \text { cheese }) / 100]+[(28.9 \%) \times(\% \mathrm{NDM}) / 100]
\end{aligned}
$$

where $\%$ IC cheese $=$ percentage of intact CN present in the natural cheese (Table 2$) ; \%$ cheese = percentage of natural cheese used in the PC formula (Table 3); $\% \mathrm{NDM}=$ percentage NDM used in the PC formula (Table 3).

Because the intact $\mathrm{CN}$ of the final process cheese food was not experimentally determined but mathematically calculated, it is referred to as calculated intact CN (CIC) in the rest of the paper.

\section{Functional Analyses (Unmelted Textural Properties)}

TPA-Hardness. For TPA analysis, the cylinders of process cheese food $(20 \mathrm{~mm} \times 30 \mathrm{~mm})$ that were filled during manufacture were removed from the copper molds and cut to a height of $20 \mathrm{~mm}$. The TPA analysis was performed using a TA.XT2 Texture Analyzer (Texture Technologies Corp., Scarsdale, NY/Stable Microsystems, Godalming, Surrey, UK) as described by Drake et al. (1999). The test conditions were uniaxial two-bite compression; 50-mm diameter cylindrical flat probe (TA-25); compression, 80\%; and crosshead speed, $0.8 \mathrm{~mm} / \mathrm{s}$. Process cheese was analyzed for TPAhardness as described by Breene (1975). Breene (1975) defines TPA-hardness as a measure of unmelted texture of a cheese that describes the firmness of the cheese.

\section{Functional Analysis (Melted Textural Properties)}

Modified Schreiber Melt Test. Meltability of each process cheese food sample was measured using the modified Schreiber test as described by Muthukumarappan et al. (1999). Each process cheese food sample was cut into discs of $28.5 \mathrm{~mm}$ diameter and $7 \mathrm{~mm}$ height. Three discs of equal weights $(5 \mathrm{~g})$ were randomly selected and kept in covered Petri plates at $20^{\circ} \mathrm{C}$ for $30 \mathrm{~min}$. The discs were then placed on $0.95-\mathrm{mm}$ thick aluminum plates $(100 \mathrm{~mm} \times 100 \mathrm{~mm})$, which were immediately transferred to an air convection oven (Gallenkamp Plus Oven, Loughborough, UK) at $90^{\circ} \mathrm{C}$. After $5 \mathrm{~min}$, the plates with the melted cheese discs were cooled to room temperature. Area of the melted cheese was measured using image-processing software (HL Image++98, Western Vision Software, Salt Lake City, UT). The meltability of process cheese was reported as the area of the melted cheese in millimeters squared.

Dynamic Rheological Analysis. Dynamic rheological analysis of each process cheese food sample was performed using a modified method as described by Sutheerawattananonda and Bastian (1998) using a rheometer (ATS Rheosystems, Rheologica Instruments Inc., Bordentown, NJ) with parallel plate geometry. Modifications of the method included the use of fine sandpaper (400 grit), which was glued to the upper plate of the rheometer to prevent sample slippage. Process cheese food samples (slice of $\sim 2.0 \mathrm{~mm}$ ) were prepared using a wire cutter.

Cylindrical cheese samples of $28.3 \mathrm{~mm}$ diameter were then cut using a cork borer. Before analysis, the PC samples were tempered to room temperature for $15 \mathrm{~min}$. During loading, the sample was placed on the lower plate and the upper plate was brought in contact with it. The exposed edge of the sample was coated with vegetable oil (Midwest Country Fare, Des Moines, IA) to minimize drying during measurement. Dynamic rheological properties $\left(\mathbf{G}^{\prime}\right.$, elastic modulus, and $\mathbf{G}^{\prime \prime}$, 
viscous modulus) were analyzed using a dynamic temperature ramp test from 30 to $90^{\circ} \mathrm{C}$ with a heating rate of $4^{\circ} \mathrm{C} / \mathrm{min}$. Frequency was maintained at $1 \mathrm{~Hz}$ with $0.5 \%$ strain and $750-\mathrm{Pa}$ stress. The gap maintained between the parallel plates was $2 \mathrm{~mm}$. Transition temperature (melting point) was defined as the temperature at which $\tan \delta=1\left(\mathrm{G}^{\prime \prime} / \mathrm{G}^{\prime}\right)$ and was recorded as the dynamic stress rheometer (DSR) - melt temperature. The $\mathrm{G}^{\prime \prime}$ values at $85^{\circ} \mathrm{C}$ were used to evaluate viscous properties at elevated temperature.

Rapid Visco Analyzer-Hot Apparent Viscosity. The Rapid Visco Analyzer (RVA; RVA-4, Newport Scientific Pty. Ltd., Warriewood, Australia) was used to measure the apparent viscosity of all the process cheese food samples. The RVA melt test continuously measures the apparent viscosity during a heating, holding, and cooling profile as described by Prow (2004). For the RVA melt test, a representative sample of PC was cut from the 1-kg block and was ground using an Osterizer blender (model 6641, Jarden Corp., Rye, NY). Fourteen grams of the ground PC was weighed into an RVA canister along with $1 \mathrm{~g}$ of propylene glycol. The RVA melt test utilizes a heating, holding, and cooling temperature profile where the temperature of the canister was raised from 25 to $85^{\circ} \mathrm{C}$ in 5 min, held for $3 \mathrm{~min}$ at $85^{\circ} \mathrm{C}$, and then cooled to $25^{\circ} \mathrm{C}$ in $6 \mathrm{~min}$. During this temperature profile, the stirring speed was held at $0 \mathrm{rpm}$ for $30 \mathrm{~s}, 20 \mathrm{rpm}$ for $30 \mathrm{~s}, 100$ rpm for $1 \mathrm{~min}$, and $300 \mathrm{rpm}$ for the remainder of the test. The RVA melt test was performed in duplicate on all PC samples. The minimum apparent viscosity (in $\mathrm{cP}$ ) during the holding period was collected from the apparent viscosity vs. time curve and is referred to as hot apparent viscosity (Prow, 2004). The RVAhot apparent viscosity is a measure of how well the cheese flows when heated to a specific temperature.

\section{Statistical Analysis}

A $2 \times 2 \times 2$ factorial design with 3 replications was used for statistical analysis to study the effect of natural cheese $\mathrm{Ca}$ and $\mathrm{P}$, residual lactose, and $\mathrm{S} / \mathrm{M}$ ratio on PC chemical and functional properties. Each replicate of the $8 \mathrm{PC}$ was treated as the blocks of the design. An ANOVA was performed to obtain the mean squares and $P$-values using Macanova 4.12 software (School of Statistics, University of Minnesota, Minneapolis). The comparisons were made at the 0.05 level of significance; the results were considered significant at $P<$ 0.05 . If the $F$-test for the factors was significant $(P<$ 0.05 ), the treatment means were compared using least significant difference test.

\section{RESULTS AND DISCUSSION}

\section{PC Composition and Chemical Properties}

Mean values of $\mathrm{PC}$ composition and chemical properties including moisture, fat, salt, total protein, total $\mathrm{Ca}$, total $\mathrm{P}, \mathrm{pH}$, and CIC of the $8 \mathrm{PC}$ are listed in Table 4 . The mean square values and the $P$-values for the PC composition and chemical properties are indicated in Table 5. There was a significant replicate effect in all the PC compositional and chemical properties $(P<$ 0.05 ) (except total protein). None of the 3 factors $(\mathrm{Ca}$ and $\mathrm{P}$, residual lactose, or $\mathrm{S} / \mathrm{M})$ and their interactions had a significant effect $(P>0.05)$ on moisture, fat, salt, and total protein contents of the manufactured PC. These results are as expected because all the PC were balanced for moisture, fat, salt, and protein (as indicated earlier). There was a significant effect $(P<0.05)$ of natural cheese $\mathrm{Ca}$ and $\mathrm{P}$ and natural cheese $\mathrm{S} / \mathrm{M}$ on total Ca, total P, and CIC of the PC. Moreover, the $\mathrm{pH}$ of the PC was significantly affected $(P<0.05)$ by natural cheese $\mathrm{Ca}$ and $\mathrm{P}$, residual lactose, and $\mathrm{S} / \mathrm{M}$.

Effect of Natural Cheese Ca and $P$. As indicated above, there was a significant effect of natural cheese $\mathrm{Ca}$ and $\mathrm{P}$ on PC total $\mathrm{Ca}$ and total $\mathrm{P}$ content (Table 4). As expected, natural cheeses with higher $\mathrm{Ca}$ and $\mathrm{P}$ content produced $\mathrm{PC}$ with higher $\mathrm{Ca}$ and $\mathrm{P}$ content (PC-HHH, PC-HHL, PC-HLH, and PC-HLL; Tables 3 and 4). The $\mathrm{pH}$ of the $\mathrm{PC}$ was also significantly affected by the natural cheese $\mathrm{Ca}$ and $\mathrm{P}$ (Table 4). Higher $\mathrm{Ca}$ and $\mathrm{P}$ natural cheese treatments produced $\mathrm{PC}$ (PCHHH, PC-HHL, PC-HLH, and PC-HLL) with higher $\mathrm{pH}$ compared with when lower $\mathrm{Ca}$ and $\mathrm{P}$ natural cheese treatments were used to manufacture PC (PC-LHH, PC-LHL, PC-LLH, and PC-LLL; Table 4). High Ca and $\mathrm{P}$ contents in a natural cheese are typically associated with a higher $\mathrm{pH}$ of that natural cheese. This is due to the increased buffering capacity of the cheese with a high $\mathrm{Ca}$ and $\mathrm{P}$ (mineral) content (Dolby et al., 1937; Upreti and Metzger, 2007). Similar effects can be expected in process cheese. In the study by Acharya and Mistry (2004, 2005), in which they manufactured process cheeses with Cheddar cheeses manufactured using milks concentrated to different levels (either by ultrafiltration or vacuum condensing), they found that as the level of concentration of milk to make the Cheddar cheese was increased, the total Ca content as well as the $\mathrm{pH}$ of the Cheddar cheese increased (Acharya and Mistry, 2004). When these Cheddar cheeses were used to manufacture process cheese, the $\mathrm{pH}$ of manufactured process cheeses was also found to be higher (Acharya and Mistry, 2005).

Natural cheese $\mathrm{Ca}$ and $\mathrm{P}$ content also significantly affected the CIC of the resulting PC. Higher $\mathrm{Ca}$ and $\mathrm{P}$ natural cheese treatments produced PC (PC-HHH, 
Table 4. Mean values $(\mathrm{n}=3)$ of the composition and chemical properties of the 8 process cheese treatments

\begin{tabular}{|c|c|c|c|c|c|c|c|c|}
\hline & \multicolumn{8}{|c|}{ Process cheese treatments ${ }^{1}$} \\
\hline & PC-HHH & PC-HHL & PC-HLH & PC-HLL & PC-LHH & PC-LHL & PC-LLH & PC-LLL \\
\hline Moisture, ${ }^{2} \%$ & 42.9 & 43.1 & 43.0 & 43.6 & 42.9 & 43.2 & 43.0 & 43.0 \\
\hline Fat, ${ }^{2} \%$ & 25.6 & 25.5 & 25.5 & 25.4 & 24.9 & 25.3 & 25.6 & 25.2 \\
\hline Salt $^{2} \%$ & 2.0 & 2.0 & 2.1 & 2.0 & 2.0 & 1.9 & 2.1 & 2.1 \\
\hline Protein, ${ }^{2} \%$ & 21.8 & 20.9 & 21.2 & 21.1 & 20.8 & 21.0 & 21.0 & 21.1 \\
\hline $\mathrm{S} / \mathrm{M},{ }^{2} \%$ & 4.7 & 4.6 & 4.9 & 4.6 & 4.7 & 4.4 & 4.9 & 4.9 \\
\hline Total $\mathrm{Ca}, \%$ & $0.39^{\mathrm{a}}$ & $0.38^{\mathrm{a}}$ & $0.39^{\mathrm{a}}$ & $0.39^{\mathrm{a}}$ & $0.35^{b}$ & $0.35^{\mathrm{b}}$ & $0.34^{b}$ & $0.33^{b}$ \\
\hline Total P, \% & $0.56^{\mathrm{a}}$ & $0.55^{\mathrm{ab}}$ & $0.56^{\mathrm{a}}$ & $0.56^{\mathrm{a}}$ & $0.48^{\mathrm{c}}$ & $0.48^{\mathrm{bc}}$ & $0.46^{\mathrm{c}}$ & $0.46^{\mathrm{c}}$ \\
\hline $\mathrm{pH}$ & $6.10^{\mathrm{ab}}$ & $5.76^{\mathrm{cd}}$ & $6.16^{\mathrm{a}}$ & $5.89^{b c}$ & $5.96^{\mathrm{abc}}$ & $5.65^{\mathrm{d}}$ & $5.99^{\mathrm{ab}}$ & $5.77^{\mathrm{cd}}$ \\
\hline $\mathrm{CIC},{ }^{3} \%$ & $18.3^{\mathrm{a}}$ & $17.7^{\mathrm{bc}}$ & $18.0^{\mathrm{ab}}$ & $17.5^{\mathrm{bc}}$ & $17.1^{\mathrm{cd}}$ & $16.5^{\mathrm{d}}$ & $17.1^{\mathrm{cd}}$ & $16.6^{\mathrm{d}}$ \\
\hline
\end{tabular}

${ }^{\mathrm{a}-\mathrm{d}}$ Means within same row not sharing common superscript are significantly different $(P<0.05)$.

${ }^{1}$ Process cheese treatments: $\mathrm{PC}-\mathrm{HHH}=$ process cheese, high $\mathrm{Ca}$ and $\mathrm{P}$, high lactose, and high salt-tomoisture (S/M); PC-HHL = process cheese, high Ca and P, high lactose, and low S/M; PC-HLH = process cheese, high $\mathrm{Ca}$ and $\mathrm{P}$, low lactose, and high $\mathrm{S} / \mathrm{M} ; \mathrm{PC}-\mathrm{HLL}=$ process cheese, high $\mathrm{Ca}$ and $\mathrm{P}$, low lactose, and low S/M; PC-LHH = process cheese, low $\mathrm{Ca}$ and $\mathrm{P}$, high lactose, and high S/M; PC-LHL = process cheese, low $\mathrm{Ca}$ and $\mathrm{P}$, high lactose, and low $\mathrm{S} / \mathrm{M} ; \mathrm{PC}-\mathrm{LLH}$ = process cheese, low $\mathrm{Ca}$ and $\mathrm{P}$, low lactose, and high $\mathrm{S} /$ $\mathrm{M} ; \mathrm{PC}-\mathrm{LLL}=$ process cheese, low $\mathrm{Ca}$ and $\mathrm{P}$, low lactose, and low $\mathrm{S} / \mathrm{M}$.

${ }^{2}$ Moisture, fat, salt, protein, and salt-to-moisture ratio (S/M) of the 8 process cheeses were not significantly different.

${ }^{3} \mathrm{CIC}=$ calculated intact $\mathrm{CN}$.

PC-HHL, PC-HLH, and PC-HLL) with higher CIC compared with when lower $\mathrm{Ca}$ and $\mathrm{P}$ natural cheese treatments were used (PC-LHH, PC-LHL, PC-LLH, and PC-LLL; Table 4). Calcium acts as a cross-linking agent within the $\mathrm{CN}$ molecules thereby limiting their flexibility. Researchers have found that, as the level of $\mathrm{Ca}$ is reduced in a model CN system, the solubility of the CN molecules increases (Sood et al., 1979; Cavalier-Salou and Cheftel, 1991). This increase in solubility of $\mathrm{CN}$ molecules may result in an increase in the availability of the caseins for hydrolysis during ripen- ing. Consequently, natural cheeses with lower $\mathrm{Ca}$ and $P$ levels should have a higher level of protein hydrolysis during ripening and less intact $\mathrm{CN}$. We reported this in a related study in which the cheeses with high $\mathrm{Ca}$ and $\mathrm{P}$ (HHH, HHL, HLH, and HLL) had a lower level of proteolysis at 2 mo of ripening compared with low $\mathrm{Ca}$ and $\mathrm{P}$ natural cheeses (Upreti and Metzger, 2006b) and therefore had a higher intact CN level (Table 2). These differences in the natural cheese intact $\mathrm{CN}$ content resulted in the observed differences in the intact $\mathrm{CN}$ content of the process cheeses.

Table 5. Mean squares and $P$-values (in parentheses) of the process cheese composition and chemical properties

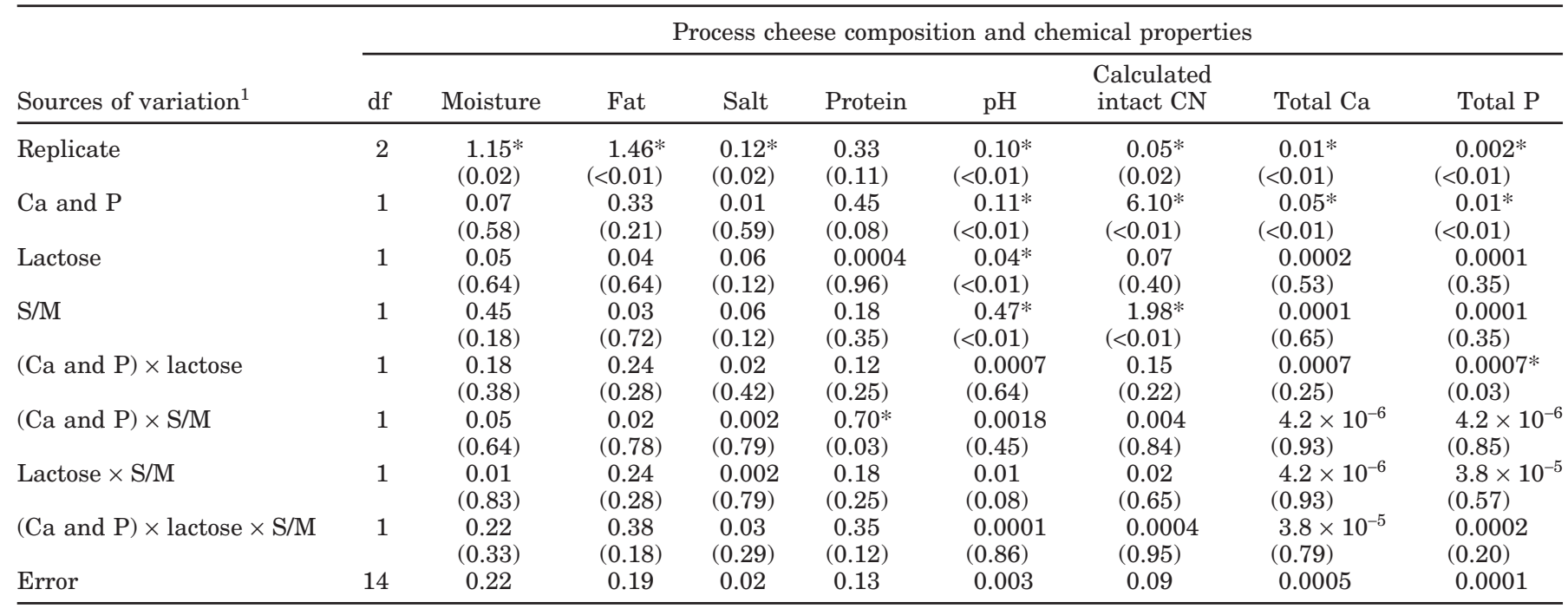

${ }^{1} \mathrm{Ca}$ and $\mathrm{P}=$ calcium and phosphorus content; $\mathrm{S} / \mathrm{M}=$ salt-to-moisture ratio.

*Statistically significant $(P<0.05)$. 
Effect of Natural Cheese Lactose Content. The natural cheese residual lactose content (at $d 1$ of ripening) significantly affected the $\mathrm{pH}$ of the resulting PC (Table 5). The natural cheese treatments with higher residual lactose produced $\mathrm{PC}$ with lower $\mathrm{pH}$ (PC-HHH, PC-HHL, PC-LHH, and PC-LHL) compared with the PC manufactured using the natural cheeses with lower residual lactose level (PC-LH, PC-HLL, PC-LLH, and PC-LLL). This can be attributed to the fact that the residual lactose in natural cheese had an effect on the final $\mathrm{pH}$ (at $2 \mathrm{mo}$ of ripening) of that cheese (Table 2; Upreti and Metzger, 2007) and this effect was carried onto the corresponding PC treatments.

Effect of Natural Cheese S/M. The natural cheese $\mathrm{S} / \mathrm{M}$ had a significant effect on the $\mathrm{pH}$ as well as the CIC of the resulting PC (Table 5). We previously reported that the $\mathrm{S} / \mathrm{M}$ in natural cheese influenced its final $\mathrm{pH}$, which was attributed to the fact that the $\mathrm{S} /$ $M$ of natural cheese has an effect on the growth and activity of starter and nonstarter lactic acid bacteria; thereby, influencing the rate and amount of conversion of residual lactose to lactic acid and other organic acids (Upreti and Metzger, 2007). This effect on the natural cheese $\mathrm{pH}$ was carried through to the PC; the PC manufactured using natural cheeses with high S/M (PCHHH, PC-HLH, PC-LHH, and PC-LLH) showed a higher $\mathrm{pH}$ compared with those manufactured using the natural cheeses with low S/M (PC-HHL, PC-HLL, PC-LHL, and PC-LLL). Moreover, as indicated above, PC manufactured using the natural cheeses with high S/M also had higher CIC when compared with PC manufactured using the natural cheeses with low S/M. This can again be attributed to the fact that the natural cheeses with higher S/M had a lower level of proteolysis (Upreti and Metzger, 2006b) and therefore higher intact casein at 2 mo of ripening (Table 2), the time when they were used to make the PC.

\section{PC Functional Properties}

Mean values of the functional properties (TPA-hardness, melt area, DSR-melt temperature, $\mathrm{G}^{\prime \prime}$ at $85^{\circ} \mathrm{C}$, and RVA-hot apparent viscosity) of the $8 \mathrm{PC}$ are indicated in Table 6 . The mean square values and the $P$ values for the PC functional properties are indicated in Table 7. There was a significant replicate effect in all PC functional properties $(P<0.05)$ except TPAhardness. There was a significant effect of natural cheese $\mathrm{Ca}$ and $\mathrm{P}$ and natural cheese $\mathrm{S} / \mathrm{M}$ on all the functional properties of the manufactured PC (Table 7). However, natural cheese residual lactose content did not have an effect on the functional properties of the PC.
Effect of Natural Cheese Ca and P. Natural cheese $\mathrm{Ca}$ and $\mathrm{P}$ content significantly affected the functional properties of the resulting PC. The TPA-hardness, melt area, and DSR-melt temperature values of the process cheeses indicate that the $\mathrm{PC}$ manufactured using the natural cheeses with high $\mathrm{Ca}$ and $\mathrm{P}$ (PCHHH, PC-HHL, PC-HLH, and PC-HLL) were firmer and less meltable than those manufactured using natural cheeses with low $\mathrm{Ca}$ and $\mathrm{P}$ (PC-LHH, PC-LHL, PC-LLH, and PC-LLL; Table 6). Moreover, the PC manufactured using natural cheeses with high $\mathrm{Ca}$ and $\mathrm{P}$ were more viscous at high temperature $\left(85^{\circ} \mathrm{C}\right)$ than those manufactured using natural cheeses with low $\mathrm{Ca}$ and $\mathrm{P}$, as indicated by higher $\mathrm{G}^{\prime \prime}$ at $85^{\circ} \mathrm{C}$ and RVAhot apparent viscosity.

Effect of Natural Cheese S/M. Natural cheese S/ $\mathrm{M}$ level also significantly affected the functional properties of the resulting process cheeses. The TPA-hardness, melt area, and the DSR-melt temperature values of the PC indicate that the PC manufactured using the natural cheeses with high S/M (PC-HHH, PCHLH, PC-LHH, and PC-LLH) were firmer and less meltable than those manufactured using natural cheeses with low S/M (PC-HHL, PC-HLL, PC-LHL, and PC-LLL; Table 6). Moreover, the PC manufactured using natural cheeses with high $\mathrm{S} / \mathrm{M}$ were more viscous at high temperature $\left(85^{\circ} \mathrm{C}\right)$ than those manufactured using natural cheeses with low S/M, as indicated by higher $\mathrm{G}^{\prime \prime}$ at $85^{\circ} \mathrm{C}$ and RVA-hot apparent viscosity.

\section{Relationship Between PC Chemical and Functional Properties}

Tables 5 and 7 indicate that natural cheese $\mathrm{Ca}$ and $\mathrm{P}$ and $\mathrm{S} / \mathrm{M}$ significantly affected the $\mathrm{pH}$, total Ca content, total $\mathrm{P}$ content, and the CIC of the resulting PC. Tables 6 and 7 indicate a significant influence of natural cheese $\mathrm{Ca}$ and $\mathrm{P}$ and $\mathrm{S} / \mathrm{M}$ on the functional properties of the resulting $\mathrm{PC}$. When the chemical properties (Table 4) of PC-LHL and PC-LLL are compared with PC$\mathrm{HHH}$ and PC-HLH, total Ca content; total $\mathrm{P}$ content; $\mathrm{pH}$; and CIC were $0.35 \%$ and $0.33 \% ; 0.48 \%$ and $0.46 \%$; 5.65 and 5.77; and $16.5 \%$ and $16.6 \%$ for PC-LHL and PC-LLL respectively, compared with $0.39 \%$ and $0.39 \%$; $0.56 \%$ and $0.56 \% ; 6.10$ and 6.16 ; and $18.3 \%$ and $18.0 \%$ for PC-HHH and PC-HLH, respectively. Similarly, comparing the functional properties (Table 6) of PCLHL and PC-LLL with PC-HHH and PC-HLH, TPAhardness; melt area; DSR-melt temperature; $\mathrm{G}^{\prime \prime}$ at $85^{\circ} \mathrm{C}$; and RVA-hot apparent viscosity were $61 \mathrm{~N}$ and $67 \mathrm{~N} ; 1,545 \mathrm{~mm}^{2}$ and $1,463 \mathrm{~mm}^{2} ; 70.6^{\circ} \mathrm{C}$ and $69.4^{\circ} \mathrm{C}$; $212 \mathrm{~Pa}$ and $352 \mathrm{~Pa}$; and $465 \mathrm{cP}$ and $570 \mathrm{cP}$ for PCLHL and PC-LLL respectively, and $130 \mathrm{~N}$ and $148 \mathrm{~N}$; $920 \mathrm{~mm}^{2}$ and $885 \mathrm{~mm}^{2} ; 76.8^{\circ} \mathrm{C}$ and $76.3^{\circ} \mathrm{C} ; 1,163 \mathrm{~Pa}$ 
Table 6. Mean values $(\mathrm{n}=3)$ of the functional properties of the 8 process cheese treatments

\begin{tabular}{|c|c|c|c|c|c|c|c|c|}
\hline \multirow[b]{2}{*}{ Functional property $^{2}$} & \multicolumn{8}{|c|}{ Process cheese treatments ${ }^{1}$} \\
\hline & PC-HHH & PC-HHL & PC-HLH & PC-HLL & PC-LHH & PC-LHL & PC-LLH & PC-LLL \\
\hline TPA-hardness, N & $130^{\mathrm{a}}$ & $82^{\mathrm{b}}$ & $148^{\mathrm{a}}$ & $86^{\mathrm{b}}$ & $94^{\mathrm{b}}$ & $61^{\mathrm{b}}$ & $79^{\mathrm{b}}$ & $67^{\mathrm{b}}$ \\
\hline DSR-melt temperature,${ }^{\circ} \mathrm{C}$ & $76.8^{\mathrm{a}}$ & $70.4^{\mathrm{b}}$ & $76.3^{\mathrm{a}}$ & $72.6^{\mathrm{ab}}$ & $72.0^{\mathrm{ab}}$ & $70.6^{\mathrm{b}}$ & $73.1^{\mathrm{ab}}$ & $69.4^{\mathrm{b}}$ \\
\hline $\mathrm{G}^{\prime \prime}$ at $85^{\circ} \mathrm{C}, \mathrm{Pa}$ & $1,163^{\mathrm{a}}$ & $678^{\mathrm{b}}$ & $1,179^{\mathrm{a}}$ & $571^{\mathrm{bc}}$ & $729^{\mathrm{ab}}$ & $212^{\mathrm{c}}$ & $744^{\mathrm{ab}}$ & $352^{\mathrm{bc}}$ \\
\hline RVA-hot apparent viscosity, $\mathrm{cP}$ & $747^{\mathrm{a}}$ & $542^{\mathrm{b}}$ & $742^{\mathrm{a}}$ & $522^{\mathrm{b}}$ & $603^{\mathrm{ab}}$ & $465^{\mathrm{b}}$ & $588^{\mathrm{ab}}$ & $570^{\mathrm{ab}}$ \\
\hline
\end{tabular}

${ }^{\mathrm{a}-\mathrm{d}}$ Means within same row not sharing common superscript are significantly different $(P<0.05)$.

${ }^{1}$ Process cheese treatments: $\mathrm{PC}-\mathrm{HHH}=$ process cheese, high $\mathrm{Ca}$ and $\mathrm{P}$, high lactose, and high salt-to-moisture $(\mathrm{S} / \mathrm{M})$; $\mathrm{PC}-\mathrm{HHL}=$ process cheese, high $\mathrm{Ca}$ and $\mathrm{P}$, high lactose, and low S/M; PC-HLH = process cheese, high Ca and P, low lactose, and high S/M; PC-HLL = process cheese, high $\mathrm{Ca}$ and $\mathrm{P}$, low lactose, and low S/M; PC-LHH = process cheese, low Ca and P, high lactose, and high $\mathrm{S} / \mathrm{M}$; PC-LHL = process cheese, low $\mathrm{Ca}$ and $\mathrm{P}$, high lactose, and low S/M; PC-LLH = process cheese, low Ca and P, low lactose, and high S/M; PC-LLL = process cheese, low $\mathrm{Ca}$ and $\mathrm{P}$, low lactose, and low $\mathrm{S} / \mathrm{M}$.

${ }^{2} \mathrm{TPA}=$ texture profile analysis; DSR = dynamic stress rheometers; RVA = rapid visco analyzer.

and $1,179 \mathrm{~Pa}$; and $747 \mathrm{cP}$ and $742 \mathrm{cP}$ for $\mathrm{PC}-\mathrm{HHH}$ and PC-HLH, respectively. It is obvious that $\mathrm{PC}$ with lower total Ca content, lower total $\mathrm{P}$ content, lower $\mathrm{pH}$, and lower CIC (PC-LHL and PC-LLL) were less firm, more meltable, and less viscous at high temperature than the $\mathrm{PC}$ with higher total $\mathrm{Ca}$ content, higher $\mathrm{pH}$, and higher CIC (PC-HHH and PC-HLH). Because the other compositional properties (moisture, fat, salt, and total protein) were not significantly different among PC, there is a relationship between $\mathrm{PC}$ total $\mathrm{Ca}$ and total $\mathrm{P}$ content, final $\mathrm{pH}$, and intact $\mathrm{CN}$ content and the functional properties of process cheese. However, the relative effect of total $\mathrm{Ca}$ content, total $\mathrm{P}$ content, $\mathrm{pH}$, and intact $\mathrm{CN}$ content on $\mathrm{PC}$ functional properties could not be determined from this study and could be the subject of future research.

\section{CONCLUSIONS}

Natural cheese $\mathrm{Ca}$ and $\mathrm{P}$ and natural cheese $\mathrm{S} / \mathrm{M}$ were found to significantly affect $\mathrm{PC}$ functional properties (unmelted texture, as well as melt properties of $\mathrm{PC})$. The results also indicated that natural cheese $\mathrm{Ca}$ and $\mathrm{P}$, residual lactose, and $\mathrm{S} / \mathrm{M}$ had significant effects on the chemical properties such as the $\mathrm{pH}$, total $\mathrm{Ca}$ content, total $\mathrm{P}$ content, and the CIC of the resulting PC. Consequently, it is not only important to balance the moisture, fat, salt, and total protein of a PC but

Table 7. Mean squares and $P$-values (in parentheses) of the process cheese functional properties

\begin{tabular}{|c|c|c|c|c|c|c|}
\hline \multirow[b]{2}{*}{ Source of variation ${ }^{1}$} & \multicolumn{6}{|c|}{ Process cheese functional properties ${ }^{2}$} \\
\hline & $\mathrm{df}$ & $\begin{array}{c}\text { TPA- } \\
\text { hardness }\end{array}$ & Melt area & $\begin{array}{c}\text { DSR-melt } \\
\text { temperature }\end{array}$ & $\begin{array}{l}\mathrm{G}^{\prime \prime} \text { at } \\
85^{\circ} \mathrm{C}\end{array}$ & $\begin{array}{l}\text { RVA-hot } \\
\text { apparent } \\
\text { viscosity }\end{array}$ \\
\hline Replicate & 2 & $\begin{array}{r}555.5 \\
(0.22)\end{array}$ & $\begin{array}{r}117,050.0^{*} \\
(0.02)\end{array}$ & $\begin{array}{l}32.4^{*} \\
(0.03)\end{array}$ & $\begin{array}{r}437,550.0^{*} \\
(0.03)\end{array}$ & $\begin{array}{r}35,835.0^{*} \\
(0.02)\end{array}$ \\
\hline $\mathrm{Ca}$ and $\mathrm{P}$ & 1 & $\begin{array}{r}7,993.5^{*} \\
(<0.01)\end{array}$ & $\begin{array}{r}345,360.0^{*} \\
(<0.01)\end{array}$ & $\begin{array}{l}45.4^{*} \\
(0.02)\end{array}$ & $\begin{array}{r}905,590.0^{*} \\
(<0.01)\end{array}$ & $\begin{array}{r}40,344.0^{*} \\
(0.03)\end{array}$ \\
\hline Lactose & 1 & $\begin{array}{l}66.7 \\
(0.66)\end{array}$ & $\begin{array}{r}1,962.0 \\
(0.77)\end{array}$ & $\begin{array}{l}2.0 \\
(0.59)\end{array}$ & $\begin{array}{r}1,472.7 \\
(0.86)\end{array}$ & $\begin{array}{r}1,536.0 \\
(0.65)\end{array}$ \\
\hline $\mathrm{S} / \mathrm{M}$ & 1 & $\begin{array}{r}8,893.5^{*} \\
(<0.01)\end{array}$ & $\begin{array}{r}783,730.0^{*} \\
(<0.01)\end{array}$ & $\begin{array}{c}92.0^{*} \\
(<0.01)\end{array}$ & $\begin{array}{r}1,502,000.0^{*} \\
(<0.01)\end{array}$ & $\begin{array}{r}126,730.0^{*} \\
(<0.01)\end{array}$ \\
\hline$(\mathrm{Ca}$ and $\mathrm{P}) \times$ lactose & 1 & $\begin{array}{c}400.2 \\
(0.29)\end{array}$ & $\begin{array}{c}117.0 \\
(0.94)\end{array}$ & $\begin{array}{l}1.0 \\
(0.70)\end{array}$ & $\begin{array}{r}22,571.0 \\
(0.51)\end{array}$ & $\begin{array}{r}4,873.5 \\
(0.43)\end{array}$ \\
\hline$(\mathrm{Ca}$ and $\mathrm{P}) \times \mathrm{S} / \mathrm{M}$ & 1 & $\begin{array}{r}1,600.7 \\
(0.05)\end{array}$ & $\begin{array}{r}44,290.0 \\
(0.18)\end{array}$ & $\begin{array}{l}12.0 \\
(0.20)\end{array}$ & $\begin{array}{r}12,881.0 \\
(0.61)\end{array}$ & $\begin{array}{r}27,068.0 \\
(0.08)\end{array}$ \\
\hline Lactose $\times \mathrm{S} / \mathrm{M}$ & 1 & $\begin{array}{l}13.5 \\
(0.84)\end{array}$ & $\begin{array}{c}2,223.4 \\
(0.76)\end{array}$ & $\begin{array}{l}4.1 \times 10^{-2} \\
(0.94)\end{array}$ & $\begin{array}{c}4.2 \\
(0.99)\end{array}$ & $\begin{array}{r}4,213.5 \\
(0.46)\end{array}$ \\
\hline$(\mathrm{Ca}$ and $\mathrm{P}) \times$ lactose $\times \mathrm{S} / \mathrm{M}$ & 1 & $\begin{array}{r}450.7 \\
\quad(0.26)\end{array}$ & $\begin{array}{r}9,882.0 \\
(0.52)\end{array}$ & $\begin{array}{l}15.0 \\
(0.16)\end{array}$ & $\begin{array}{r}23,188.0 \\
(0.50)\end{array}$ & $\begin{array}{r}6,800.7 \\
(0.35)\end{array}$ \\
\hline Error & 14 & 333.5 & $22,747.0$ & 6.8 & $48,490.0$ & $7,321.2$ \\
\hline
\end{tabular}

${ }^{1} \mathrm{Ca}$ and $\mathrm{P}=$ calcium and phosphorus content; $\mathrm{S} / \mathrm{M}=$ salt-to-moisture ratio.

${ }^{2} \mathrm{TPA}=$ texture profile analysis; DSR = dynamic stress rheometer; RVA = rapid visco analyzer.

*Statistically significant $(P<0.05)$. 
also to control the final $\mathrm{Ca}, \mathrm{P}, \mathrm{pH}$, and intact $\mathrm{CN}$ to produce a process cheese with targeted functional properties. Future work should involve evaluation of the individual influence of the total $\mathrm{Ca}$, total $\mathrm{P}, \mathrm{pH}$, and intact $\mathrm{CN}$ of $\mathrm{PC}$ on the $\mathrm{PC}$ functional properties when all other chemical properties of the PC such as moisture, fat, salt, and total protein are constant.

\section{REFERENCES}

Acharya, M. R., and V. V. Mistry. 2004. Comparison of effect of vacuum-condensed and ultrafiltered milk on Cheddar cheese. J. Dairy Sci. 87:4004-4012.

Acharya, M. R., and V. V. Mistry. 2005. Effect of vacuum-condensed or ultrafiltered milk on pasteurized process cheese. J. Dairy Sci. 88:3037-3043.

Anderson, D. L., V. V. Mistry, R. L. Brandsma, and K. A. Baldwin. 1993. Reduced fat Cheddar cheese from condensed milk. 1. Manufacture, composition, and ripening. J. Dairy Sci. 76:2832-2844.

AOAC. 1995. Official Methods of Analysis. 16th ed. Association of Official Analytical Chemists International, Arlington, VA.

Arnott, D. R., H. A. Morris, and W. B. Combs. 1957. Effect of certain chemical factors on the melting quality of process cheese. J. Dairy Sci. 40:957-963.

Atherton, H. V., and J. A. Newlander. 1977. Tests for fat: Babcock, Gerber, and Mojonnier. Pages 71-116 in Chemistry and Testing of Dairy Products. 4th ed. AVI Publ. Co., Inc., Westport, CT.

Barker, C. R. 1947. Practical suggestions on the manufacture of process cheese. Nat. Butter Cheese J. 38:42,44,46.

Bradley, R. L., Jr., and M. A. Vanderwarn. 2001. Determination of moisture in cheese and cheese products. J. AOAC 84:570-592.

Breene, W. M. 1975. Application of texture profile analysis to instrumental food texture evaluation. J. Texture Stud. 6:53-82.

Brooks, I. B., G. A. Luster, and D. G. Easterly. 1970. A procedure for the rapid determination of the major cations in milk by atomic absorption spectrophotometry. Atomic Absorption Newsletter 9:93-94.

Caric, M., M. Gantar, and M. Kalab. 1985. Effects of emulsifying agents on the microstructure and other characteristics of process cheese-A review. Food Microstruct. 4:297-312.

Cavalier-Salou, C., and J. C. Cheftel. 1991. Emulsifying salts influence on characteristics of cheese analogs from calcium caseinate. J. Food Sci. 56:1542-1551.

Czulak, J., J. Conochie, B. J. Sutherland, and H. J. M. Van Leeuwen. 1969. Lactose, lactic acid, and mineral equilibria in Cheddar cheese manufacture. J. Dairy Res. 36:93-101.

Dolby, R. M., F. H. McDowall, and A. K. R. McDowell. 1937. Studies on the chemistry of Cheddar cheese making. V. Factors influencing the acidity and mineral content of cheese. J. Dairy Res. $8: 74-85$.

Drake, M. A., P. D. Gerard, V. D. Truong, and C. R. Daubert. 1999. Relationship between instrumental and sensory measurements of cheese texture. J. Texture Stud. 30:451-476.

FDA. 2006. 21 CFR, Part 133.169 to 133.180. United States Food and Drug Administration. Department of Health and Human Services, Washington, DC.

Garimella Purna, S. K., A. Pollard, and L. E. Metzger. 2006. Effect of formulation and manufacturing parameters on process cheese food functionality: I. Trisodium citrate. J. Dairy Sci. 89:23862396 .
Marshall, R. T. 1992. Chemical and physical methods. Pages 433529 in Standard Methods for the Examination of Dairy Products. 16th ed. American Public Health Association, Washington, DC. Metzger, L. E. 2003. Nutrition labeling using a computer program. Pages 1-6 in Food Analysis Laboratory Manual. S.S. Nielsen, ed. Kluwer Academic, New York, NY.

Meyer, A. 1973. Processed Cheese Manufacture. Food Trade Press Ltd., London, UK.

Muthukumarappan, K., Y. C. Wang, and S. Gunasekaran. 1999 Modified Schreiber test for evaluation of Mozzarella cheese meltability. J. Dairy Sci. 82:1068-1071.

Nair, S., V. V. Mistry, and K. R. Nauth. 2004. Reduction of salt $(\mathrm{NaCl})$ losses during the manufacture of Cheddar cheese. J. Dairy Sci. 87:2831-2838.

Olson, N. F., D. G. Vakaleris, and W. V. Price. 1958. Acidity and age of natural cheese as factors affecting the body of pasteurized process cheese spread. J. Dairy Sci. 41:1005-1016.

Piska, I., and J. Štětina. 2003. Influence of cheese ripening and rate of cooling of the processed cheese mixture on rheological properties of processed cheese. J. Food Eng. 61:551-555.

Prow, L. A. 2004. Development of a melt test for process cheese spread and process cheese product using the rapid visco analyzer (RVA). MS Thesis. University of Minnesota, St. Paul.

Shimp, L. A. 1985. Process cheese principles. Food Technol. 39:63$64,66,68,70$.

Sood, S. M., D. K. Gaind, and R. K. Dewan. 1979. Correlation between micelle solvation and calcium content. N.Z. J. Dairy Sci. Technol. 14:32-34.

Sutheerawattananonda, M., and E. D. Bastian. 1998. Monitoring process cheese meltability using dynamic stress rheometry. J. Texture Stud. 29:169-183.

Sutherland, B. J., and G. W. Jameson. 1981. Composition of hard cheese manufactured by ultrafiltration. Aust. J. Dairy Technol. $36: 136-143$.

Templeton, H. L., and H. H. Sommer. 1930. Some observations on processed cheese. J. Dairy Sci. 13:203-220.

Thomas, M. A. 1973. The Manufacture of Processed Cheese-Scientific Principles. 1st ed. New South Wales Department of Agriculture, Richmond, NSW, Australia.

Thomas, T. D., and K. N. Pearce. 1981. Influence of salt on lactose fermentation and proteolysis in Cheddar cheese. N.Z. J. Dairy Sci. Technol. 16:253-259.

Upreti, P., and L. E. Metzger. 2006a. Influence of calcium and phosphorus, residual lactose, and salt-to-moisture ratio on Cheddar cheese quality: Manufacture and composition. J. Dairy Sci. 89:420-428.

Upreti, P., and L. E. Metzger. 2006b. Influence of calcium and phosphorus, residual lactose, and salt-to-moisture ratio on Cheddar cheese quality: Proteolysis during ripening. J. Dairy Sci. 89:444-453.

Upreti, P., and L. E. Metzger. 2007. Influence of calcium and phosphorus, residual lactose, and salt-to-moisture ratio on Cheddar cheese quality: $\mathrm{pH}$ changes during ripening. J. Dairy Sci. 90:1-12.

Vakaleris, D. G., N. F. Olson, and W. V. Price. 1962. Effects of proteolysis of natural cheese on body and melting properties of pasteurized process cheese spread. J. Dairy Sci. 45:492-494.

Wiles, P. G., I. K. Gray, and R. C. Kissling. 1998. Routine Analysis of Proteins by Kjeldahl and Dumas Methods: Review and Interlaboratory Study Using Dairy Products. J. AOAC Int. 81:620632.

Zehren, V. L., and D. D. Nusbaum. 2000. Processed Cheese. 2 ed. Cheese Reporter Publishing Co. Inc., Madison, WI. 